\title{
Considering Student's Reading Interest in Developing Blended Reading Assessment in Higher Education
}

\author{
Yulmiati Yulmiati ${ }^{*}$, Muhammad Zaim², and Atmazaki Atmazaki ${ }^{3}$ \\ ${ }^{123}$ Universitas Negeri Padang \\ *Corresponding author. Email: yulmiati.academic@gmail.com
}

\begin{abstract}
Students' reading interest is important to know to develop reading assessment. By considering students' reading interest, teacher can select material for assessment that was close to students' favorite reading material and reading setting. This research is aim at identifying students' reading interest especially in Basic Reading course in higher education. This research is a descriptive study with a questionnaire collection technique. The questionnaire was distributed via google form trough WhatsApp group of the students who learn Basic Reading subject in higher education. The questionnaire with 27 items has responded by 53 students that selected using simple random sampling. The questionnaire has been validated theoretically and statistically using SPPS for the quality of the instruments. The data were analyzed descriptively using Statistical Package for the Social Sciences (SPSS) by involving means and standard deviation. The result of the research shows that students' reading interest was fair, by the mean score of 3.55 . It means that the students did not show a strong interest in reading. They still need support to make them enjoy in reading. The degree of their enjoyment in reading still needs improvement. Basic Reading subject is the potential to make them interested in reading, by considering their favorite reading material as the result of this research.
\end{abstract}

Keywords: Reading Interest, Blended Assessment, Reading

\section{INTRODUCTION}

Reading is recognized as the essential skill to learn in English as a second/ foreign language (ESL/EFL). Because reading has functions a means to the end in the process of acquiring the language that is commonly exposed in written texts [1]. Reading is not only as a source of information but also as a means of acquiring knowledge about language [2]. By reading, it helps the learners to extend foreign language by indicating of their understanding toward the reading text. While learners easily comprehend the text, language learning has a better language acquisition.

However, in 2009 Kusmana claimed that Indonesia was at the lowest level of reading interest among other East Asian countries, our students can absorb only $30 \%$ of the text [3]. This fact warns us about the low literacy level of our students. A teacher has responsibility to higher students' reading interest trough learning process involving in giving an assessment.

By considering their reading interest in assessment, the students will be motivated doing exercises and tasks given from teacher. The teacher can ask the students to select what they should read and do for pleasure of their reading activities. As reading influence determine the success of the students in higher education, they must be equipped with this skill [4]
Furthermore, the awareness about students' reading interest will assist parents, teachers and society more effectively to know students' reading needs [3]. When students having interests for specific object or activity, they will be more active in participation involving their attention, concentration and happiness [5].

In other case of reason in reading, students do not only want to read, but also they have to read. Especially in Basic Reading course, students read English material as a task that must be obtained as the process of learning. Teachers' can select assessment material and activities by considering students' preference to higher their reading interest. The students can comprehend reading English text easily if their teacher consider students' reading interest based on specific characteristics [6]. Consequently, teachers help the students with reading for understanding for their academic success because they can access the source of all the knowledge in the world.

Some studies have an effort about reading interest and reading comprehension. The students' interest toward reading has significance effect to reading comprehension [6]. It was also found that students' reading interest has positive correlation to their comprehension of the text, reading more encourage understanding more [7]. In addition, students' 
motivation to participate in the online assessments were increased, thereby their reading interests in higher level [4]. Then, subcomponents of psycho-behavioral dimensions represented reading interest, where the factor of reading interest represented reading in printed settings, online reading, social media reading, academic reading, and recreational reading [8]. Self-concept in academic has shown the relationship between teacher support and reading interest completely [9]. In other fact, reading interest facilitated the direct effects of achievement motivation on students' discourse analysis [10]. These researches show that how reading interest is essential in academic life.

All the researches are closely related with this study. However, the research about students' reading interest to consider reading assessment was very limited. In this study, the researchers identified students' reading interest in order to develop blended assessment model in higher education. The researchers concern to Basic Reading subject in this study because the purpose of this subject is to prepare EFL students in having a good modality in reading skill [11]. If the students are good in basic reading, it is easy for them to study the next level of reading skill.

\subsection{Reading Interest}

Reading is the valuable skill in life that develop ability to think in creative way, beside the ability to think critically, analytically and imaginatively [5]. In reading activities, students' reading interest motivated students to read. In other side, the difficulties in reading can be appeared that make students feel frustrated in learning, consequently they were and angry in reading English texts in learning a second language because they have lack interesting in reading English text [3]. Teachers' awareness on students' reading interest can be a good solution of this problem. Reading interest encourages students to read easily which higher students motivation to enjoy reading.

In reading much, one has access to a wider knowledge through the varieties of reading materials like journal, books, magazines, and newspapers (Khairuddin, 2013). So, reading is the mean to access all the knowledge in the world.

Students need support from teacher to make them strong in reading interests. When students received more teacher support, they read more because of having greater interest in reading [9]. To improve reading interest, the teacher essentially choose the relevant text for students, then, link the text and the activities to reallife experiences [7]. To make reading interesting and insightful for students, teachers need to guide them in developing students' proficiency and their own interest in reading [12]. Ugwu (2019) adds that interest is one of students' qualities in their learning tasks that relate to students' academic achievement. The more students' interest in a subject, the more they spend time in learning it. Students' interests in reading give the better process in comprehending what they read.

Interest usually relates to a particular object and activity (Schiefele, 2009). Students who are interested to an activity with a certain topic, such as reading about education or sports, they can enjoy reading about these topics. Generally we may think about motivation to read, but specifically we think about interest in reading specific topic [13].

Meanwhile, reading interest refers to the degree of students' reading enjoyment. [9]. It is also defined as the number of books to read in a month, the number of times to read in a week, and the favorite genres and types of English reading materials [3]. Reading interest is also categorized as whether students like to read in their spare time or not, and whether they like to read at home or go to the library. Besides, technology and multimedia resources provide reading text that interesting for students such as novels, comic, story book, and magazines, beside digital texts that are always available that can be shared to students whenever and wherever [13]. In short, reading interest is the degree of reading enjoyment and the preference of place and time of reading, genre and types of reading materials and reading setting.

Reading interest is also related to students' critical thinking skills, if the learners have high critical thinking, it is potential for them to understand a text that contains hard words [14]. Reading interest is a feeling of special attention to reading that make us having good habit in reading actively [6]. The high interest in reading, the success the reader will be, then, the failure of reading may be caused by lack of interest.

\subsection{Blended Reading Assessment}

Reading assessment is the reflection of the understandings of what reading is, how it works, and how it is used providing picture of students' reading challenges and accomplishments [15]. The purpose of assessment is to stimulate students in thinking, reacting to new situations, reviewing and revising work, evaluating their own and others' work, and communicating results verbally or visually [16]. In addition, it guides the students to be creative in learning activities which contains character values [17]. Teacher can determine assessment activities based on students interest. So, the evaluation process can improve students' participation in class because they do the activities based on what they like to do.

Moreover, the authentic reading assessment aims to assess many kinds of literacy abilities in certain contexts [18]. Contextually, literacy involves reading and responding to newspaper articles, editorials and a novel, finding out about the people in different culture, or using information from a bus schedule or manual equipment. Those ideas show the real-life contexts of students.

In this globalization era, the demand of using of technology in education relates to the increasing of educators' knowledge and skill in using it. Blended learning is the use of different blends of technology and pedagogy in both campus-based and distance programs [19]. In assessing students, it is better for educators to implement blended assessment. The research found that blended teaching provides autonomous learners that 
leaded by teachers within a feasible and scientific method in higher education [20].

Blended learning is considered as a way for teachers to begin with the technology utilization into the language classroom that provide computer that connected to internet. As a result, both the teachers and the learners can work at any time and in any place [19]. Blended teaching combines online and offline teaching to enrich learners' autonomous in learning, and improve their ability in discovering, analyzing, and solving problems [20]. The material in reading assessment that based on students' reading interest supports students to enjoy assessment.

\section{METHOD}

This study is aimed at identifying students' reading interest in higher education. This study is descriptive research using a questionnaire as the instrument in collecting data. The questionnaire consists of 27 items that distributed via google form to the students who learn Basic Reading course in higher education, Indonesia. There were 53 students responded the questionnaire which selected using random sampling technique. The respondents chose one of the five options based on Likert scale to show their reading interest toward the questionnaire items. Related to the quality of the instrument, the researchers determined validity and reliability of the questionnaire. The questionnaire was validated theoretically by two experts with the result very valid by the score 95 . Then, the questionnaire was also validated statistically using SPSS analysis. The result of validation analysis inform that all items of the questionnaire for measuring students' reading interest in this research were valid. Because $r$ count of the items were higher than 0.266 as $\mathrm{r}$ table from 53 respondents.

In addition, in determining the reliability of the questionnaires, the researchers used Cronbach's Alpha formula through SPSS. As the result, the reliability of the questionnaire was very high, about 0.90 . The table below shows the result of reliability analysis.

Table 1. Reliability Statistics of Students' Reading Interest

\begin{tabular}{|r|r|}
\hline Cronbach's Alpha & N of Items \\
\hline .900 & 27 \\
\hline
\end{tabular}

The data from questionnaire were analyzed using the statistical descriptive analysis providing means and standard deviation.

\section{RESULT}

Students' reading interest was considered as the important characteristic of the students in designing the prototype of assessment model. Before developing the assessment, the teachers should know what the students prefer to about assessment activities and material.

After collecting the data trough questionnaire and analyzing quantitatively, we reached the research finding. The descriptive statistical analysis presented in form of number related to the mean and standard deviation about students' reading interest. The result of analysis can be seen from table 2 .

Table 2. The result of Students' Reading Interest

\begin{tabular}{|c|c|c|c|c|}
\hline Indicators & $\begin{array}{c}\text { Sub } \\
\text { Indicators }\end{array}$ & $\mathrm{N}$ & Mean & $\begin{array}{c}\text { Std. } \\
\text { Deviation }\end{array}$ \\
\hline $\begin{array}{l}\text { Reading as } \\
\text { hobbies }\end{array}$ & $\begin{array}{l}\text { Favorite } \\
\text { activity }\end{array}$ & 53 & 3.64 & .963 \\
\hline \multirow{2}{*}{$\begin{array}{l}\text { The times of } \\
\text { reading in a } \\
\text { week }\end{array}$} & Every day & 53 & 3.17 & .849 \\
\hline & $3-6$ days & 53 & 3.53 & .823 \\
\hline \multirow{2}{*}{$\begin{array}{l}\text { Reading in } \\
\text { spare time }\end{array}$} & At home & 53 & 3.81 & 1.020 \\
\hline & At library & 53 & 3.42 & .865 \\
\hline \multirow{3}{*}{$\begin{array}{l}\text { The books } \\
\text { read in a } \\
\text { month }\end{array}$} & $>6$ books & 53 & 2.66 & 1.073 \\
\hline & $2-6$ books & 53 & 2.79 & 1.150 \\
\hline & $<2$ books & 53 & 2.85 & 1.199 \\
\hline \multirow{9}{*}{$\begin{array}{l}\text { The favorite } \\
\text { genres of } \\
\text { English } \\
\text { reading } \\
\text { material }\end{array}$} & Fantasy & 53 & 3.34 & .960 \\
\hline & Mystery & 53 & 4.21 & .840 \\
\hline & $\begin{array}{l}\text { Historic } \\
\text { fiction }\end{array}$ & 53 & 4.11 & 1.121 \\
\hline & Romance & 53 & 3.45 & .889 \\
\hline & Horror & 53 & 3.87 & 1.256 \\
\hline & Thriller & 53 & 3.89 & 1.031 \\
\hline & $\begin{array}{l}\text { Science } \\
\text { fiction }\end{array}$ & 53 & 3.72 & 1.133 \\
\hline & Education & 53 & 3.98 & .909 \\
\hline & Poetry & 53 & 3.32 & 1.156 \\
\hline \multirow{8}{*}{$\begin{array}{l}\text { Students' } \\
\text { favorite } \\
\text { types of } \\
\text { English } \\
\text { reading } \\
\text { material }\end{array}$} & Story Book & 53 & 3.92 & 1.207 \\
\hline & Comic & 53 & 4.19 & .962 \\
\hline & Novel & 53 & 3.94 & 1.167 \\
\hline & $\begin{array}{l}\text { Article in } \\
\text { internet }\end{array}$ & 53 & 3.79 & .906 \\
\hline & $\begin{array}{l}\text { Encyclope } \\
\text { dia }\end{array}$ & 53 & 3.40 & .817 \\
\hline & $\begin{array}{l}\text { Academic } \\
\text { book }\end{array}$ & 53 & 3.38 & .790 \\
\hline & Magazine & 53 & 2.70 & 1.030 \\
\hline & Newspaper & 53 & 3.02 & .971 \\
\hline \multirow{3}{*}{$\begin{array}{l}\text { Reading } \\
\text { setting } \\
\text { Average }\end{array}$} & Online & 53 & 3.57 & 1.010 \\
\hline & Printed & 53 & 4.17 & .826 \\
\hline & & & 3.55 & \\
\hline
\end{tabular}

From the table above it was found that students responded that reading as hobby was fair (3.64). It indicates that reading has not students' favorite activities yet. Related to reading in spare time, the result 
shows that students preferred to read at home (3.81), rather than reading in library (3.42). The times of reading in a week was not high too, their everyday reading was only 3.17. As English department students, they actually have demanded to read English text every day. However, students' frequency in reading was still far from the demand. Meanwhile, the books read in a month, the data show that the students were seldom reading book in a month, because almost all the students responded disagree about reading book. It can be interpreted that the students were lack of reading books.

Regarding to the favorite genres of English reading material, the students were preferred to read mystery as reading material as the highest mean score (4.21). Then the students like historic fiction reading material (4.11), followed by education (3.98), thriller (3.89), horror 3.87 ), science fiction (3.72), romance (3.45), fantasy (3.34) and poetry (3.32) as the lowest score. Generally, the students' preferences in genre of reading were neutral. It indicates that the students did not show their favorite genre as they have. Teachers must select the genre of English reading material. Regarding to the developing of assessment, teacher must consider what the students like to read.

Moreover, students' favorite types of English reading material were found that students' were preferred to read comic (4.19). They were also like reading novel (3.94), followed by reading story book (3.92), article in internet (3.79), encyclopedia (3.40), academic book (3.38), reading newspaper (3.02), and magazine (3.70) as the lowest score. The result of students preference related to types of English material will be considered in selecting assessment material later.

From the reading setting, the students were preferred to read through printed (4.17) instead of reading in online (3.57). It is indicated that they like the combination of online and printed reading material, because the different of the score was not too significance. However, printed reading material was more considered than online material in developing assessment model.

Generally, students' reading interest was fair, by the mean score 3.55 , the shows the neutral condition. They still need support to make them enjoy in reading. The degree of their enjoyment in reading still needs improvement. Basic Reading subject is potential make them interest in reading. So, in selecting assessment material, the teacher needs to design the reading task that cover students' reading interest.

The findings above show us that each student has their own characteristics in reading. One of their characteristics is reading interest. Each student has unique reading favorite place, time, quantity, genre, and types of English reading material. In line with this notion, students should struggle in raising their reading interest and improve their reading habits whether academic or non-academic books that obtained through both printed media and electronic media, because the interest in reading influenced students' ability in analyzing discourse [10]. Therefore, approaching how students' reading interest in learning Basic Reading is necessary. When the teacher link the circumstance to match the student's interest with reading activities and material in designing task, truly, help the students in enjoying reading that influence to their reading achievement. Teacher awareness of students' interest also might bring an idea to create acceptable classroom atmosphere.

\section{CONCLUSION}

From this research it is noticed that reading interest and reading skill are inseparable. The teacher needs to know students' reading interest in case of the degree of reading enjoyment related to their favorite place and time of reading, genre and types of reading materials and reading setting. These preferences surely determine students' academic success in reading. A good level of reading interest constructs effective reading classroom that can be seen from the result of reading assessment.

From the data analysis, the students have various reading interests as the characteristics of their individual. The highest score for each indicator of reading interest shows the preference of the students in learning Basic Reading. The results of this research can be the reference of the teachers who teach Basic Reading subject in higher education. Teacher's awareness of students' interest is hoped helping students' growth in their basic reading achievement.

\section{AUTHORS' CONTRIBUTIONS}

There were three authors who gave their valuable contribution in conducting this research. Their participation in case of collecting data, analysing and writing report made the success of this study.

\section{ACKNOWLEDGMENTS}

The researchers intend to say special thanks for DPRM Dikti in supporting this research financially. In addition, for the students to whom the data have been collected, we want to give our appreciation and thanks for your cooperative response in giving the information about your reading interest.

\section{REFERENCES}

[1] M. Rahimi and N. Sadeghi, "Impact of reciprocal teaching on EFL learners , reading comprehension," Res. Appl. Linguist., vol. 6, no. 1, pp. 64-86, 2014.

[2] M. Juyandegan, "The Relationship between SelfEsteem and Reading Comprehension of EFL Iranian Pre-University Learners," Int. J. Asian Soc. Sci., vol. 5, no. 5, pp. 303-313, 2016, doi: 10.18488/journal.1/2016.6.5/1.5.303.313.

[3] Z. Khairuddin, "A Study of Students' Reading Interests in a Second Language," Int. Educ. Stud., vol. 6, no. 11, pp. 160-170, 2013, doi: 10.5539/ies.v6n11p160.

[4] E. Y. Rahayu and H. Februariyanti, "Implementation of Online Reading Assessments to Encourage Reading Interests," English Lang. 
Teach., vol. 8, no. 11, p. 197, 2015, doi: 10.5539/elt.v8n11p197.

[5] Alhamdu, "Interest and Reading Motivation," Psikis J. Psikol. Islam., vol. 1, no. 1, pp. 1-10, 2015, doi: 10.19109/psikis.v1i1.552.

[6] Y. Y. I. Reski, "The Correlational Study Between Students Interest and the Students Reading Comprehension," IDEAS J. English Lang. Teach. Learn. Linguist. Lit., vol. 6, no. 1, pp. 44-54, 2018, doi: 10.24256/ideas.v6i1.17.

[7] M. Käsper, K. Uibu, and J. Mikk, "Language teaching strategies' impact on third-grade students' reading outcomes and reading interest," Int. Electron. J. Elem. Educ., vol. 10, no. 5, pp. 601610, 2018, doi: 10.26822/iejee.2018541309.

[8] N. H. P. S. Putro and J. Lee, "Reading interest in a digital age," Read. Psychol., vol. 38, no. 8, pp. 778-807, 2017, doi: 10.1080/02702711.2017.1341966.

[9] W. Zhao, Y. Song, Q. Zhao, and R. Zhang, "The effect of teacher support on primary school students' reading engagement: the mediating role of reading interest and chinese academic selfconcept," Educ. Psychol., vol. 39, no. 2, pp. 236253, 2019, doi: 10.1080/01443410.2018.1497146.

[10] F. Aprilia, N. Lustyantie, and Z. Rafli, "The effect of reading interest and achievement motivation on students' discourse analysis competence," J. Educ. e-Learning Res., vol. 7, no. 4, pp. 368-372, 2020, doi: 10.20448/journal.509.2020.74.368.372.

[11] S. S. Sukandi and D. N. Syafar, "EFL students' responses to learning basic reading and writing skills," Stud. English Lang. Educ., vol. 5, no. 1, pp. 40-53, 2018, doi: 10.24815/siele.v5i1.8419.

[12] E. O. Ugwu, "Effect of Student TeamsAchievement Divisions and Think-Pair-Share on Students' Interest in Reading Comprehension," $J$. Educ. Res. Pract., vol. 9, no. 1, pp. 316-330, 2019, doi: 10.5590/jerap.2019.09.1.22.

[13] S. E. Springer, S. Harris, and J. A. Dole, "From Surviving to Thriving: Four Research-Based Principles to Build Students' Reading Interest," Read. Teach., vol. 71, no. 1, pp. 43-50, 2017, doi: $10.1002 /$ trtr.1581.

[14] S. Zubaidah, A. D. Corebima, S. Mahanal, and Mistianah, "Revealing the relationship between reading interest and critical thinking skills through remap GI and remap jigsaw," Int. J. Instr., vol. 11, no. 2, pp. 41-56, 2018, doi: 10.12973/iji.2018.1124a.

[15] P. Afflerbach, Essential Reading on Assessment. Newark, DE: The International Reading Association, 2010.

[16] H. P. Sutarto and M. P. D. Jaedun, "Authentic assessment competence of building construction teachers in indonesian vocational schools," J. Tech. Educ. Train., vol. 10, no. 1, pp. 91-108, 2018, doi: 10.30880/jtet.2018.10.01.008.

[17] E. F. Prastikawati, "EFL Learners' Responses on the Use of Performance-based Assessment," Lensa
Kaji. Kebahasaan, Kesusastraan, dan Budaya, vol. 8 , no. 1, p. 75, 2018, doi: 10.26714/lensa.8.1.2018.75-86.

[18] E. H. Hiebert, S. W. Valencia, and P. P. Afflerbach, "Understanding authentic reading assessment: Definitions and Perspectives," in Authentic Reading Assessment: Practice and Possibilities, California: TextProject, Inc, 2014.

[19] M. Milad, "Blended Learning Approach: Integrating Reading and Writing Research Skills to Improve Academic Writing," Arab J. Appl. Linguist., vol. 3, no. 3, pp. 23-55, 2017, [Online]. Available: http://www.arjals.com.

[20] X. Liu, S. Li, and X. Dun, "Study on Blended Learning Model for College English Teaching Based on Moodle System," vol. 130, no. Mcei, pp. 489-493, 2016, doi: 10.2991/mcei-16.2016.101.

[21] O. F. Tavsanli, "Examining the Reading Habits, Interests, Tendencies of the Students Studying at the Faculty of Education and Analyzing the Underlying Reason Behind Their Preferences," Eur. J. Educ. Res., vol. 6, no. 2, pp. 145-156, 2017, doi: 10.12973/eu-jer.6.2.145. 